\title{
Bone cells linked to creation of fresh eggs in mammals
}

A claim that stem cells in bone marrow and Nature 436, 309; 2005). Nature has been told that two senators, Kay Bailey Hutchison (Republican, Texas) and Norm Coleman (Republican, Minnesota), have also suggested 'compromise' bills. One would allow funding for research on cell lines created since the president's policy was announced until now. The other would allow researchers to use only 'spare' embryos created for in vitro fertilization currently existing at fertility clinics.

These bills could still pull Senate support away from the core measure - passed by the House and favoured by most scientists. As majority leader, Frist gets to decide how and when to put each bill to the vote when the Senate reconvenes next month after a long recess.

Erika Check

UNAVAILABLE blood can restock mammalian ovaries with eggs is raising hackles among reproductive biologists. If true, the finding opens up avenues for delaying the menopause and preserving fertility in female chemotherapy patients. It also raises issues for women who have had bone-marrow transplants, by implying that subsequent children could be the genetic offspring of the donor.

Supporters of the work, which is headed by Jonathan Tilly at Harvard Medical School, have hailed it as a compelling challenge to the standard view of how ovaries work. "I see amazing implications coming from this work," says Kutluk Oktay, a physician at New York Presbyterian Hospital who pioneered ovarian transplants

"The paper is an outstanding challenge to a dogma." in women. But critics are dismayed that Tilly is already discussing the implications for women when, they say, he has yet to prove his case in mice.

Tilly first caused a stir in 2004, when his team published a paper suggesting that adult mouse ovaries can produce new eggs (J. Johnson et al. Nature 428, 145-150; 2004). The work countered the view that female mammals are born with a store of eggs, and that when the store runs low, the ovary shuts down and menopause ensues. Biologists are still debating the claim. "It has never been reproduced as far as I am aware," says Allan Spradling, a developmental biologist at the Carnegie Institution in Baltimore.

Now, Tilly has proposed something even

more radical. His team found that bone-marrow stem cells in both mice and women express genes typical of germ cells. In mice, these genes cycle in unison with the same markers in the ovary (J. Johnson et al. Cell 122, 303-315; 2005). Tilly proposes that these stem cells can travel to the ovaries, and that ovaries might signal to bone marrow, via an unidentified factor, for new stocks of eggs. "That factor could be of immense value therapeutically," he says, for example in treating premature menopause (see page 606).

To test the idea, his team transplanted bone marrow or blood cells to mice that were either genetically sterile, or which had been given doses of chemotherapy that should destroy their eggs. Within two months of the bone-marrow transplants,

the researchers say, the mice regenerated hundreds of follicles - eggs encased by surrounding cells - at various stages of development, that persisted for at least a year. "That was amazing," says Tilly. And just 30 hours after the blood transfusions, several new eggs were visible.

Such rapid restocking leaves other researchers incredulous. Alan Trounson, a stem-cell researcher at Monash University in Melbourne, Australia, says that the quick appearance of eggs is unexpected and surprising.

Critics also doubt whether the new eggs come from the transplants. Tilly labelled his blood-transfusion cells with a protein that glows green, then showed the dye was present in the eggs. But Spradling says the eggs could have absorbed the dye from the blood.

Tilly's supporters argue that such scepticism is an understandable reaction to a radical idea. "The paper is an outstanding challenge to a dogma," says Oktay, adding that the idea is consistent with his finding that ovarian transplant patients seem to ovulate for longer than expected. "I don't think any revolution could be bloodless."

To prove the case, everyone agrees that Tilly must produce baby mice from eggs that come from bone-marrow transplants or blood transfusions. "We have tons of experiments under way to address this," he told Nature. "Should we show that, it's case closed."

Follicles may regenerate and produce new eggs, thanks to stem cells in bone marrow and blood.
IMAGE FOR COPYRIGHT REASONS

Claire Ainsworth 